\begin{tabular}{|c|c|c|}
\hline 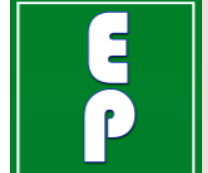 & $\begin{array}{c}\text { International Journal of Current Research } \\
\text { and Academic Review }\end{array}$ & \\
\hline $\begin{array}{l}\text { EXCELLENT } \\
\text { PUBLISHERS }\end{array}$ & $\begin{array}{c}\text { ISSN: 2347-3215 (UnIIne), ; Volume s , : Number } 3 \text { (March-2017) } \\
\text { Journal homepage: http://www.ijcrar.com }\end{array}$ & \\
\hline
\end{tabular}

doi: $\underline{\text { https://doi.org/10.20546/ijcrar.2017.503.014 }}$

\title{
Ecofriendly Bioremediation of Malachite Green, a Triphenylmethane Dye by Textile Effluent Acclimatized Bacterial Strain - Chromohalobacter sp. Strain IAK-7
}

\author{
S. Aswin Kumar ${ }^{1}$, N. Arunagirinathan ${ }^{2}$, S. Vijayanand ${ }^{3}$, J. Hemapriya ${ }^{4}$ and V. Indra ${ }^{1} *$ \\ ${ }^{I}$ Department of Zoology, Presidency College, Chennai, Tamilnadu, India \\ ${ }^{2}$ Department of Microbiology, Presidency College, Chennai, Tamilnadu, India \\ ${ }^{3}$ Department of Biotechnology, Thiruvalluvar University, Vellore, Tamilnadu, India \\ ${ }^{4}$ Department of Microbiology, DKM College, Vellore, Tamilnadu, India \\ *Corresponding author:
}

\section{Abstract}

Environmental pollution has been recognized as one of the major problems of the modern world. The increasing demand for water and the dwindling supply has made the treatment and reuse of industrial effluents as an attractive option. 7 bacterial isolates, designated as IAK-1 to IAK-7 were found to be effective in decolorizing Malachite Green. The superior strain with the highest decolorization efficiency was identified as Chromohalobacter sp. Strain IAK-7. Dye decolorization of Malachite Green was found to be maximized after $24 \mathrm{~h}$ of incubation. Increase in dye concentration was found to be inversely proportional to the decolorization of Malachite Green. HPLC and FTIR analysis revealed the degradation of the parental dye molecule.
\end{abstract}

\section{Article Info}

Accepted: 28 February 2017

Available Online: 20 March 2017

\section{Keywords}

Chromohalobacter sp., Malachite

Green, Textile effluents,

Triphenylmethane dye.

\section{Introduction}

At present scenario, environmental pollution is a major socio-economic and also a health problem. Among the various types of environment pollution, water pollution is a major concern. Nowadays, water pollution has become a matter of great concern in our society. Most of the water pollutions are related to the industrial effluents. Water is life but now a-days due to the advancement in industrialization, it is spoiling a lot. Environmental pollution has been recognized as one of the major problems of the modern world. The increasing demand for water and the dwindling supply has made the treatment and reuse of industrial effluents as an attractive option. Textile effluents are of global concern because they color the drains and ultimately the receiving water bodies (Olukanni et al., 2006). Textile industries consume a considerable amount of water in their manufacturing processes. Considering both the volume and the effluent composition, the textile industry is rated as the most polluting among the industrial sectors. Therefore treatment of industrial effluent containing aromatic compounds becomes necessary prior to their final discharge into the environment (Shyamala et al., 2014).

Physico-chemical methods have major limitations such as economically unfeasible, unable to remove the recalcitrant azo dyes and their metabolites, involves complicated procedures, more energy consumption and chemical usage. Whereas biodecolorization has been proposed as eco-friendly, generates less sludge and less expensive. Biological dye removal techniques are based on the microbial biotransformation of dyes. Many 
researchers have demonstrated the partial or complete biodegradation of dyes by pure and mixed cultures of bacteria, actinomycetes, fungi and algae (Stolz, 2001; Dong et al., 2003; Hemapriya et al., 2010). Bioremediation is a pollution control process that uses the biological systems to catalyze the degradation or transformation of various toxic chemicals into less harmful forms. Microorganisms for dye decolorization may be obtained simply by the isolation of existing dye degrading cultures from the textile effluent samples, by the adaptation of promising strains to the conditions present in the textile effluents or by the construction of suitable organisms employing genetic engineering methods (Kandelbauer et al., 2004).

The members of triphenylmethane family are animal carcinogens. The Food and Drug Administration (FDA) nominated Malachite Green, a triphenylmethane dye as a priority chemical for carcinogenicity testing by the National Toxicology Program 1993 (Srivastava et al., 2000). Malachite Green and its reduced form, leucomalachite green, may persist in edible fish tissues for extended periods of time. Therefore there are both environmental and human health concerns about bioaccumulation of Malachite Green and leucomalachite green in terrestrial and aquatic ecosystems (Parshetti et al., 2006). The present study focuses on the ecofriendly bioremediation of Malachite Green, a triphenylmethane dye by textile effluent acclimatized bacterial strain -

\section{Materials \& Methods}

\section{Sample Collection and Physico-chemical analysis}

The sampling area was the textile industries and dyeing units located in and around Kanchipuram, Tamil Nadu, India. The effluent samples from both textile industries and dyeing units were characterized by its dark color and extreme turbidity. Physico-chemical properties of the effluent samples such as TS, TDS, TSS, BOD, COD, pH and color were analyzed (APHA, 1980).

\section{Azo Dye Used}

The commonly used textile azo dye, Malachite Green used in this study was procured from a local textile dyeing unit. Stock solution was prepared by dissolving 1 $\mathrm{g}$ of Malachite Green in $100 \mathrm{ml}$ distilled water. The dye solution was sterilized by membrane filtration, since azo dyes may be unstable to moist-heat sterilization. All the chemicals used in this study were of the highest purity available and of an analytical grade.
Isolation and Screening of Bacterial Strains Decolorizing Azo dyes

Effluent samples were serially diluted and spread over basal nutrient agar medium $\mathrm{pH}$ was adjusted to 7.0 before autoclaving and incubated at $37^{\circ} \mathrm{C}$ for 5 days. Colonies surrounded by halo (decolorized) zones were picked and streaked on nutrient agar plates containing azo dyes. The plates were re-incubated at $37^{\circ} \mathrm{C}$ for 3 days to confirm their abilities to decolorize Malachite Green.

\section{Decolorization Assay}

$1 \mathrm{ml}$ of $24 \mathrm{~h}$ old culture of IAK-7 strain was inoculated in $100 \mathrm{ml}$ of nutrient broth containing $50 \mathrm{ppm}$ of Malachite Green and re-incubated at $37^{\circ} \mathrm{C}$ till complete decolorization occurs. Suitable control without any inoculum was also run along with experimental flasks. $1.0 \mathrm{ml}$ of sample was withdrawn every $12 \mathrm{~h}$ and centrifuged at 10,000 rpm for $15 \mathrm{~min}$. Decolorization extent was determined by measuring the absorbance of the culture supernatant, using UV-visible spectrophotometer (Hitachi U 2800), according to Hemapriya et al. (2010).

$$
\text { Decolorization efficiency }(\%)=\frac{\text { Dye (i) }- \text { Dye }(r)}{\text { Dye }(i)} \times 100
$$

Where, Dye (i) refers to the initial dye concentration and Dye (r) refers to the residual dye concentration. Decolorization experiments were performed in triplicates.

\section{Optimization of Various culture Conditions for Bacterial Biomass and Azo dye decolorization by Bacterial Isolates}

\section{Effect of Incubation Time and Dye Concentrations}

The effect of incubation time and dye concentration on both bacterial biomass and dye decolorizing ability of the isolate was studied. This was carried out by incubating the bacterial strains at different incubation time (0-36 h) and various dye concentrations (100-500 ppm).

\section{Analysis of Biodegraded samples by HPLC and FTIR}

Biodegradation of Malachite Green was monitored by High Performance Liquid Chromatography (HPLC) and Fourier Transform Infra Red (FTIR) spectroscopy. 


\section{HPLC Analysis of Decolorized Sample}

Ten $\mathrm{ml}$ of decolorized samples were taken after $24 \mathrm{~h}$ of incubation, centrifuged at $12,000 \mathrm{~g}$ for $30 \mathrm{~min}$, and filtered through $0.45 \mu \mathrm{m}$ membrane filter (Millipore). The filtrates were then extracted with diethyl ether and flash evaporated in rotary vacuum evaporator in temperature controlled water bath $\left(50^{\circ} \mathrm{C}\right)$ and residues were dissolved in $2 \mathrm{ml}$ of HPLC grade methanol and used for analysis. These extracted samples were analyzed by HPLC having a mobile phase of 50:49.6:0.4\% (methanol: water: disodium hydrogen phosphate).

\section{FTIR Analysis of Decolorized Samples}

The biodegraded azo dye samples were characterized by FTIR spectroscopy. The analysis results were compared with the control dye. The FTIR analysis was done in the mid IR region (400-4000 $\left.\mathrm{cm}^{-1}\right)$ with 16 scan speed. The samples were mixed with spectroscopically pure $\mathrm{KBr}$ in the ratio (5:95). The pellets were fixed in sample holder and then analyzed (Saratale et al., 2009; Shyamala et al., 2014).

\section{Results and Discussion}

Environmental biotechnology is constantly expanding its efforts in the biological treatment of colored textile effluents, which is an environmental friendly and lowcost alternative to physico-chemical decomposition processes. Wastewater from textile industries pose a threat to the environment as large amount of chemically different dyes are used for various industrial applications such as textile dyeing and a significant proportion of these dyes enter the environment via wastewater (Dayaram and Dasgupta, 2008). The presence of dyes imparts an intense color to effluents, which leads to environmental as well as aesthetic problems (Singh and Singh, 2006). The treatment of azo-dye-containing wastewaters still presents an arduous task and a technical challenge (Pandey et al., 2007).

\section{Physico-Chemical Analysis of Effluent Samples}

Textile effluent samples collected from the local Textile Industries at Kanchipuram were bluish black in color with pungent smell. The average temperature at the sampling sites was around $35^{\circ} \mathrm{C}$ at day time. The physico-chemical characteristics of the effluent samples were shown in the Table.1. The $\mathrm{pH}$ value of the effluent samples was found to be alkaline (10.42). Total Dissolved solids of the effluent sample were found to be found to be $9.64 \mathrm{mg} / \mathrm{l}$. BOD value of the sample was found to be $110 \mathrm{mg} / \mathrm{l}$. However, the COD value was maximum in the effluent sample $(1032 \mathrm{mg} / \mathrm{ml})$. The electrical conductivity was recorded as 16.69 .

\section{Isolation, Screening and Identification of bacterial strains decolorizing textile dyes}

Seven bacterial isolates, designated as IAK-1 to IAK-7 were found to be effective in decolorizing Malachite Green. Out of 07 isolates, IAK-7 was found to be the superior strain with the highest decolorization efficiency (Table 2). Based on the morphological, cultural, biochemical characteristics and 16S rRNA sequencing, the bacterial strain IAK-7 was identified as Chromohalobacter sp. Strain IAK-7.

\section{Optimization of dye decolorizing ability of Chromohalobacter sp. Strain IAK-7}

\section{Effect of incubation time}

Incubation time played a substantial role in maximizing the decolorization of Malachite Green by Chromohalobacter sp. Strain IAK-7. Dye decolorization by the isolate was found to be growth dependent, since considerable dye decolorization was noticed in the fermentation broth as soon as the bacterial strains entered the late exponential phase $(\sim 16 \mathrm{~h})$ and the activity reached the maximum level in stationary phase $(\sim 24 \mathrm{~h})$. However Bacillus cereus strain DC11 decolorized Acid Blue-25 (an anthraquinone dye), Malachite Green (triphenylmethane dye) and Basic Blue-25 (azo dye) after 6, 4 and $2 \mathrm{~h}$ respectively (Deng et al., 2008) (Fig. 2).

\section{Effect of dye concentration}

The influence of different dye concentrations (100-500 $\mathrm{ppm})$ were investigated on decolorization of Malachite Green by Chromohalobacter sp. Strain IAK-7. The results revealed that the decolorization rate of both the isolates was optimized in the presence of initial dye concentration of $100 \mathrm{ppm}$ (Fig. 3). As the dye concentration increased in the culture medium, a gradual and directly proportional decline in color removal was attained. At high concentration (500 ppm), Malachite Green greatly suppressed decolorization ability of Chromohalobacter sp. Strain IAK-7. Similar results were reported by many researchers (Hemapriya and Vijayanand, 2013; Shyamala et al., 2014). 
Table.1 Physicochemical characterization of the textile effluent

\begin{tabular}{|c|c|c|}
\hline S.No & Parameters & $\begin{array}{c}\text { Untreated Effluent } \\
\text { sample }\end{array}$ \\
\hline 01. & $\mathrm{pH}$ & 10.42 \\
\hline 02. & Temperature $\left({ }^{\circ} \mathrm{C}\right)$ & 35 \\
\hline 03. & Electrical conductivity & 16.69 \\
\hline 04. & TDS $(\mathrm{mg} / \mathrm{l})$ & 9.614 \\
\hline 05. & COD $(\mathrm{mg} / \mathrm{l})$ & 1032 \\
\hline 06. & BOD $(\mathrm{mg} / \mathrm{l})$ & $110 \mathrm{mg} / \mathrm{l}$ \\
\hline 07. & Color $(\mathrm{OD}$ at $600 \mathrm{~nm})$ & 0.230 \\
\hline
\end{tabular}

Table.2 Decolorization efficiency of bacterial strains on Malachite Green

\begin{tabular}{|c|c|c|}
\hline S.No & Isolate & $\begin{array}{c}\text { Decolorization } \\
\text { Efficiency (\%) }\end{array}$ \\
\hline 01. & IAK-1 & 61.22 \\
\hline 02. & IAK-2 & 70.12 \\
\hline 03. & IAK-3 & 71.64 \\
\hline 04. & IAK-4 & 67.64 \\
\hline 05. & IAK-5 & 66.64 \\
\hline 06. & IAK-6 & 70.22 \\
\hline 07. & IAK-7 & 90.22 \\
\hline
\end{tabular}

Fig.1 Chemical structure of Malachite Green<smiles>CN=C1C=CC(=C(c2ccccc2)c2ccc(N(C)C)cc2)C=C1</smiles>

Fig.2 Effect of Incubation Time on Decolorization of Malachite Green by IAK-7 strain

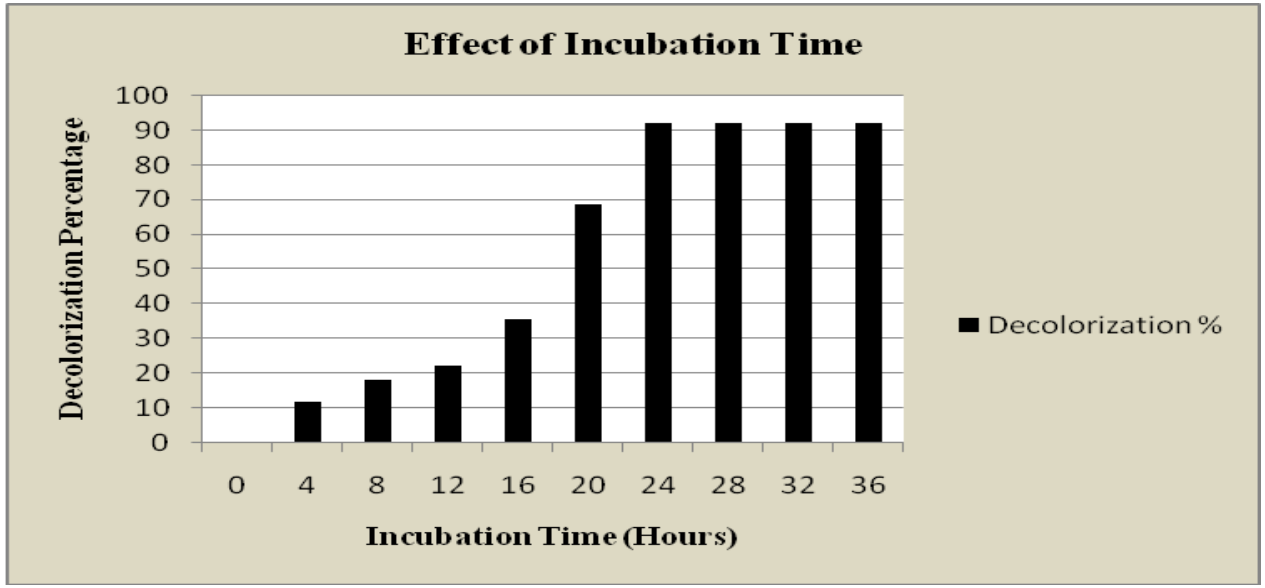


Fig.3 Effect of Dye concentration on Decolorization of Malachite Green by IAK-7 strain

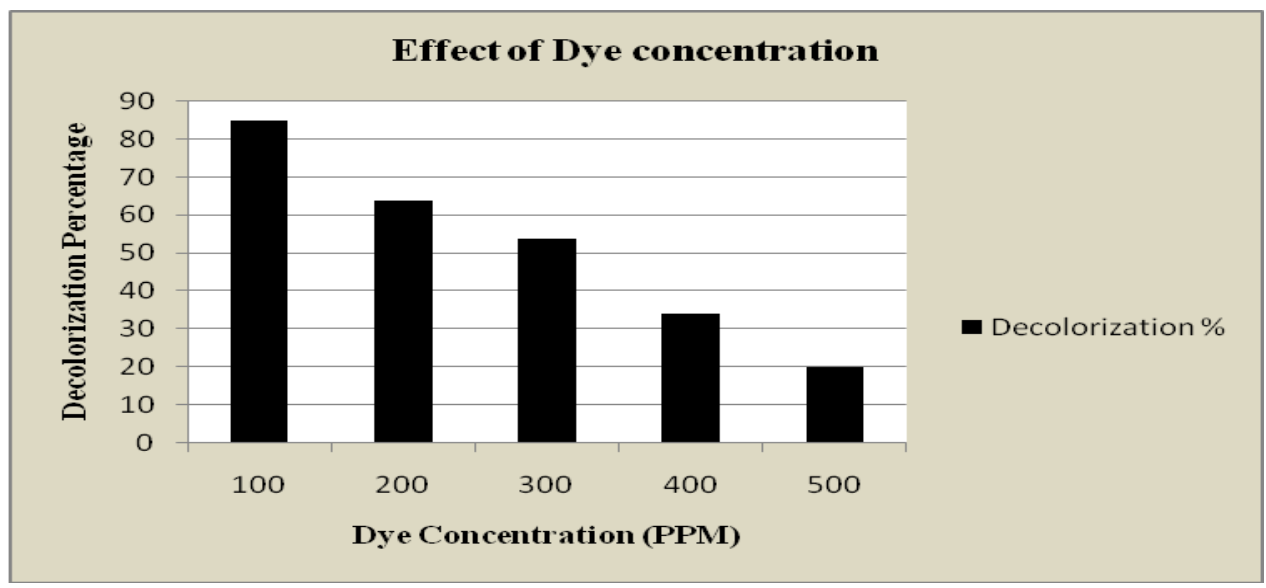

Fig.4 FT-IR analysis of the Malachite Green (control)

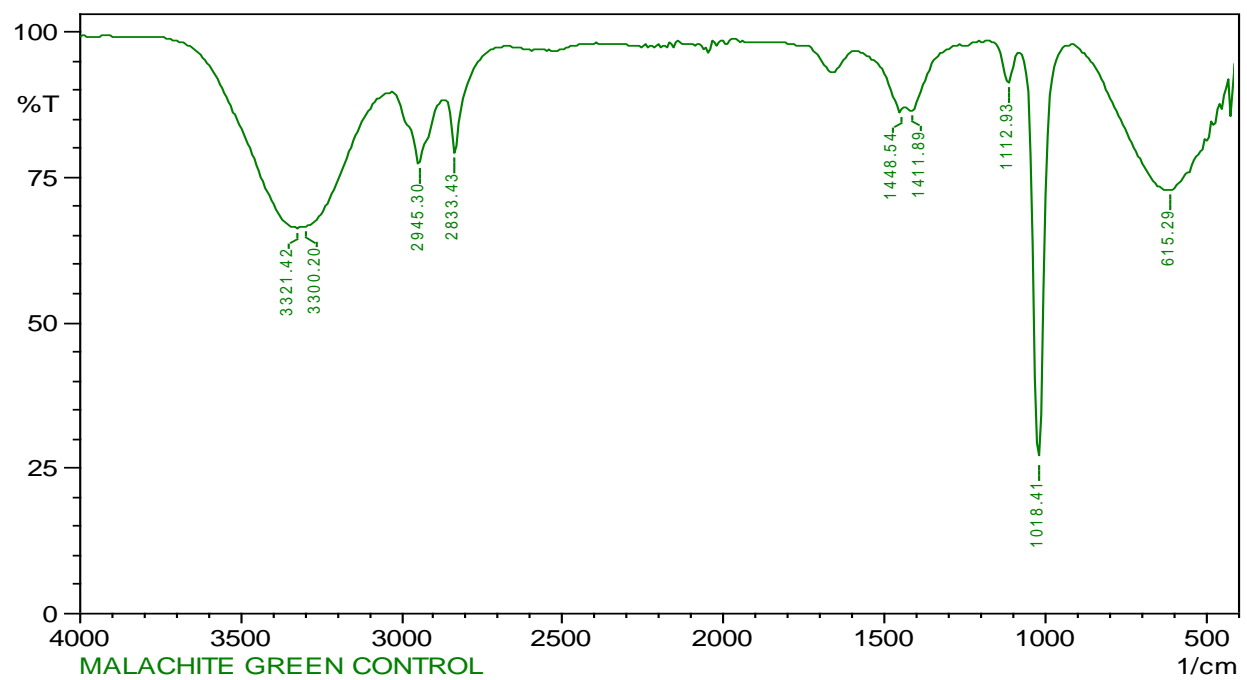

Fig.5 FT-IR analysis of biodegraded Malachite Green sample

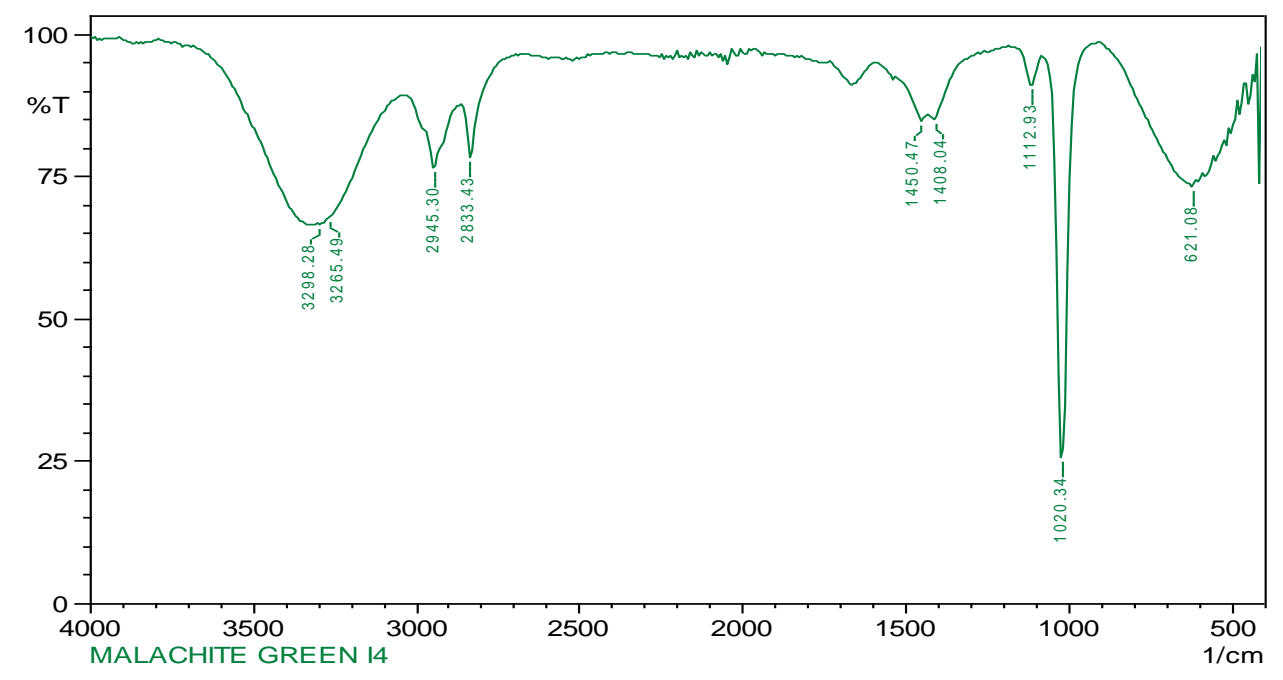




\section{Analysis of biodegraded samples by HPLC and FTIR}

Decolorization of dyes may take place either by adsorption (Aravindhan et al., 2007) or degradation (Kumar et al., 2007). In the case of adsorption, dyes are only adsorbed onto the surface of bacterial cells, whereas new compounds come into being when dyes are degraded by bacterial enzymes during the degradation process. The exact mechanism of azo dye reduction is not clearly understood yet. To disclose the possible mechanism of the dye decolorization, the products of biotransformation of Malachite Green were analyzed by HPLC and FTIR.

\section{HPLC Analysis of decolorized samples}

The HPLC analysis of Malachite Green dye sample collected at $0 \mathrm{~h}$ incubation showed 1 major peak with retention time of $2.080 \mathrm{~min}$. As the decolorization progressed, the biodegradation of parent compound was observed with 03 detectable peaks (retention time 1.761, 2.098 and 2.738) at $24 \mathrm{~h}$ extracted metabolites, however major peak was not observed at $2.080 \mathrm{~min}$ (Data not shown), clearly indicating the biodegradation of Malachite Green dye by Chromohalobacter sp. Strain IAK-7.

\section{FTIR Analysis of decolorized samples}

FT-IR spectra of Malachite Green parent dye displays peaks at 3321, 2945, 1448 and $1411 \mathrm{~cm}^{-1}$, for $-\mathrm{OH}$ and $\mathrm{NH}$ stretching vibration, aromatic $-\mathrm{CH}$ stretching vibration, $>\mathrm{C}=\mathrm{O}$ stretching and $-\mathrm{N}=\mathrm{N}$ - stretching vibration, respectively. Peak at 619 shows the presence of $-\mathrm{Br}$ on the dye (Fig. 4). The FT-IR spectra of degradation product displays peak at $3298 \mathrm{~cm}^{-1}$ for $-\mathrm{OH}$ stretching indicating hydroxylation of the product, a peak at 2925 and $1450 \mathrm{~cm}-1$ for $-\mathrm{CH}$ and $>\mathrm{C}=\mathrm{O}$ stretching, for the formation of an intermediate with carbonyl group. The peak of $-\mathrm{Br}$ is disappeared in the product indicating the debromination or dehalogenation reaction, clearly indicating the degradation of Malachite Green by Chromohalobacter sp. Strain IAK-7 (Fig. 5). Similar result was reported by Shyamala et al. (2014).

\section{References}

Aravindhan, R., J.R.Rao and B.U.Nair. (2007). Removal of Basic Yellow dye from aqueous solution by sorption on green alga Caulerpa scalpelliformis. J. Haz. Mat., 142:68-76.
Dayaram, P. and D.Dasgupta. (2008). Decolorization of synthetic and textile wastewater using Polyporus rubidus. J. Environ. Biol., 29(6):831-836.

Deng, D., J.Guo, G.Zeng and G.Sun. (2008). Decolorization of anthraquinone, triphenylmethane and azo dyes by a new isolated Bacillus cereus strain DC11. Int. Biodetor. Biodegrad., 62:263-269.

Dong, X., J.Zhou and Y.Liu. (2003). Peptone-induced biodecolorization of Reactive Brilliant Blue (KNR) by Rhodocycus gelatinosus XL-1. Proc. Biochem., 39:89-94.

Hemapriya, J and S.Vijayanand. (2013). Bioremediation of Structurally different textile dyes by a novel bacterial consortium. Int.J.Curr.Microbiol.Appl.Sci., 2(11):212- 226.

Hemapriya, J., Rajesh Kannan and S.Vijayanand. (2010). Bacterial decolorization of textile azo dye Direct Red-28 under aerobic conditions. J.Pure Appl.Microbiol., 4(1):309-314.

Kandelbauer, K., A.Erlacher, A.C.Paulo and G.Guebitz. (2004). Laccase-catalyzed decolorization of the synthetic azo dye Diamond Black PV 200 and of some structurally related derivatives. Biocatal. Biotransform., 22:331-339.

Kumar, K., S.S.Devi, K.Krishnamurthi, D.Dutta and T.Chakrabarti. (2007). Decolorization and detoxification of Direct Blue-15 by a microbial consortium. Bioresour. Technol., 98:3168-3171.

Olukanni, O.D., A.A.Osuntoki and G.O.Gbenle. (2006). Textile effluent biodegradation potentials of textile effluent-adapted and non-adapted bacteria. Afr. J. Biotechnol., 5(20):1980-1984.

Pandey, A., P.Singh and L.Iyengar. (2007). Bacterial decolorization and degradation of azo dyes. Int. Biodetor. Biodegrad., 59:73-84.

Parshetti, G., S.Kalme, G.Saratale and S.Govindwar. (2006). Biodegradation of Malachite Green by Kocuria rosea MTCC 1532. Acta Chim. Slov., 53:492-498.

Saratale, R.G., G.D.Saratale, D.C.Kalyani, J.S.Chang and S.P.Govindwar. (2009). Enhanced decolorization and biodegradation of textile azo dye Scarlet $\mathrm{R}$ by using developed microbial consortium-GR. Bioresour. Technol., 100: 24932500.

Shyamala, A., J.Hemapriya, K. Vadakkan and S.Vijayanand. Bioremediation of Methyl Orange, a synthetic textile azo dye by a halotolerant bacterial strain Int.J.Curr.Research.Academic review. 2(8): 373-381. 
Singh, V.K. and J.Singh. (2006). Toxicity of industrial wastewater to the aquatic plant Lemna minor L. J. Environ. Biol., 27:385-390.

Srivastava, S., R.Sinha and D.Roya. (2000). Bacterial decolorization of azo dyes. Aqua. Toxicol., 66:319-329.

\section{How to cite this article:}

Aswin Kumar, S., N. Arunagirinathan, S. Vijayanand, J. Hemapriya and Indra, V.2017. Ecofriendly Bioremediation of Malachite Green, a Triphenylmethane Dye by Textile Effluent Acclimatized Bacterial Strain - Chromohalobacter sp. Strain IAK-7. Int.J.Curr.Res.Aca.Rev. 5(3), 93-99. doi: https://doi.org/10.20546/ijcrar.2017.503.014 